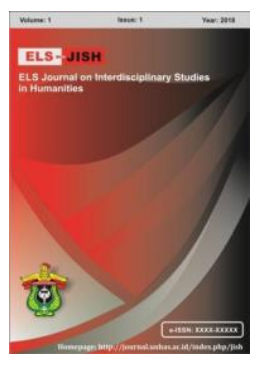

ELS-JISH

ELS Journal on Interdisciplinary Studies on Humanities

Volume 3 Issue 2, 2020

ISSN (print) : 2621-0843

ISSN (online) : 2621-0835

Homepage : http://journal.unhas.ac.id/index.php/jish

\title{
A Case Study of Pre-Service Teachers' Enabling TPACK Knowledge: Lesson Design Projects
}

\author{
Agustina Tyarakanita ${ }^{1}$, Endah Kurtianti ${ }^{2}$, Endang Fauziyati ${ }^{3}$ \\ ํㅗustinatyarakanita@student.uns.ac.id
}

\begin{abstract}
Teacher education program are expected to be able in developing pre-service teachers that capable in integrating three domains of technology, pedagogy, and content knowledge (TPACK) for future classroom practices. Every teacher program may be varied and has their own ways in developing TPACK knowledge and skill for pre-service teachers. However, the investigation of lesson design as one of instructional design resulted from the teacher program is rare especially concern on the quality of each domain within lesson design and challenges that were raised within the process of lesson plan making. Therefore, this study aims to explores the TPACK component within of pre-service teacher lesson design project of master degree of teacher education program in Indonesian University through analysing the lesson design project and conducting semi structure interview to provide the justification of determining of each component in the lesson design. The findings show that pre-service teachers' lesson plan has been represented the domain of TPACK, but there were some domains that not showing strong representation. Also, this study found that the challenges faced by the pre-service teachers were mostly as the reason of lack teaching experiences.
\end{abstract}

Keywords: challenges, pre-service teacher, TPAC.

How to cite: Tyarakanita, A., Kurtianti, E., \& Fauziati.,E. (2020). A Case Study of Pre-Service Teachers' Enabling TPACK Knowledge: Lesson Design Projects. ELS Journal on Interdisciplinary Studies in Humanities, 3(2), 158-169. DOI: 10.34050/els-jish.v3i2.10006

\section{Introduction}

To maximize the use of technology in classroom practices as the reason for 21st-century demand, teachers are expected to be capable of bringing up technology integrated into classroom practices. Nowadays, the educational systems include teaching and learning processes in the classroom are expected to be matched with the digital revolution (Caena \& Redecker, 2019). Pre-service program is one of the programs that supposed to be capable of preparing teachers before taken part in real classroom practices. As stated by Mishra \& Koehler (2006), to prepare technology integration for pre-service teachers, the teachers' education program needs to develop the knowledge of pedagogical practices, technology skills, and content knowledge in which all the domains are interrelated each other. Moreover, Gill \& Dalgarno (2017) emphasized that nowadays, pre-service teachers are surrounded by the use of the latest

${ }^{12,3}$ Universitas Sebelah Maret, Indonesia 
technology during their teacher training preparation program. Previous studies on investigating the teacher education program with digital technology use are showing more vigorous development of TPACK knowledge within the program (Valtonen et al., 2019).

Several studies have been revealed that pre-service teachers are showing proper development of all domains of TPACK during the graduate preparation program (Gill \& Dalgarno, 2017; Redmond \& Peled, 2019). Another study also revealed that pre-service teachers who had more constructivist perceptions of teaching using mobile devices, such as conveniently facilitating students' understanding or supporting student learning more actively, appeared to attain better quality technology integration in their lesson plans than those pre-service teachers with traditional conceptions (Tsai \& Tsai, 2019). However, what kind of support provided by preparation programs may be varied, and it needs further investigation to know the challenges and success for preparing them with technology integration for their prospective profession as teachers and benefitted for improving the future teachers' education programs. The previous study on the lesson design of pre-service teachers revealed that they are capable of integrating three aspects of the TPACK and provide justification for each aspect and learning activities (Noortje Janssen et al., 2019). However, besides justifying the integrated domains of TPACK, this study will also investigate the quality of lesson plans based on each component of TPACK domain and challenges that faced in integrating technology for lesson design project.

To know the enactment of TPACK within pre-service teachers of master teacher education programs, this study will examine pre-service teachers' lesson design in order to know how technology integration is reflected. The literature supporting this study examined the TPACK framework and currently takes place within master teacher education programs supporting technology integration for the teaching-learning process. This lesson plan will be analyzed based on the three-domain of TPACK (Mishra \& Koehler, 2006) and semistructured interviews will be conducted to clarify and find out several challenges they are facing during designing lesson plans for teaching English skills (Christ et al., 2019). This study also provides stories related to their past experience of technology integration in their graduate teacher program before. The data analysis of this study is conducted through examining the narrative transcript, and both interview, and story before taking part in the pre-service teachers' program, by using hybrid thematic analysis (Fereday \& Muir-Cochrane, 2006). Before conducting an interview, all of the pre-service teachers are signing the informed consent form to maintain ethical consideration.

\subsection{TPACK}

In recent years, the study of technological knowledge has been moving toward technology integration with concern on the three aspect of technology, pedagogy, and content knowledge (Mishra \& Koehler, 2006;

In order to measure the extent of technology integration represented in the pre-service teacher lesson projects, this study uses the TPACK framework to define the Technology, Pedagogical, and Content Knowledge (TPACK) 
domains and clarify the judgment beneath their consideration in determining the learning activities and technology integration through the interview process.

This study use TPACK framework as the reason that this framework is adequate to develop the teachers' knowledge as root for designing and implementing instruction for classroom practices with digital technology through three foundation knowledge areas (figure 1); 'technological knowledge (TK), pedagogical knowledge (PK), and content knowledge (CK) as well as the three areas combined; technological pedagogical knowledge (TPK), technological content knowledge (TCK), and pedagogical content knowledge (PCK)' (Mishra \& Koehler, 2006). The following table is a specific description of three primary knowledge within the foundation of TPACK and how four major knowledge interact (Koehler et al., 2014, p.102).

Table 1. TPACK framework description

\begin{tabular}{|c|c|}
\hline Knowledge Components & Description \\
\hline Content knowledge (CK) & $\begin{array}{l}\text { Any knowledge related to subject } \\
\text { matter that teacher responsible for } \\
\text { teaching. }\end{array}$ \\
\hline Pedagogical knowledge (PK) & $\begin{array}{l}\text { Teachers' knowledge related to } \\
\text { instructional practice, strategies, } \\
\text { and methods for the teaching- } \\
\text { learning process. }\end{array}$ \\
\hline Technology knowledge (TK) & $\begin{array}{l}\text { Teachers' knowledge about old and } \\
\text { new technology that can be } \\
\text { integrated with curriculum. }\end{array}$ \\
\hline $\begin{array}{l}\text { Technological } \\
\text { knowledge (TPK) }\end{array}$ & $\begin{array}{l}\text { Technology can constrain on } \\
\text { pedagogy practices. Knowledge } \\
\text { often restricted on "the technology, } \\
\text { their representational and functional } \\
\text { capabilities." }\end{array}$ \\
\hline $\begin{array}{l}\text { Technological } \\
\text { knowledge (TCK) }\end{array}$ & $\begin{array}{l}\text { Relationship between technology } \\
\text { and content knowledge. }\end{array}$ \\
\hline $\begin{array}{l}\text { Pedagogical content knowledge } \\
\text { (PCK)' }\end{array}$ & $\begin{array}{l}\text { Particular topic or issues that } \\
\text { represented and adopted based on } \\
\text { the learners' interest. }\end{array}$ \\
\hline $\begin{array}{l}\text { Technological, pedagogical, and } \\
\text { content knowledge (TPACK) }\end{array}$ & $\begin{array}{l}\text { Knowledge of three components of } \\
\text { technology, pedagogy, and content } \\
\text { knowledge }\end{array}$ \\
\hline
\end{tabular}




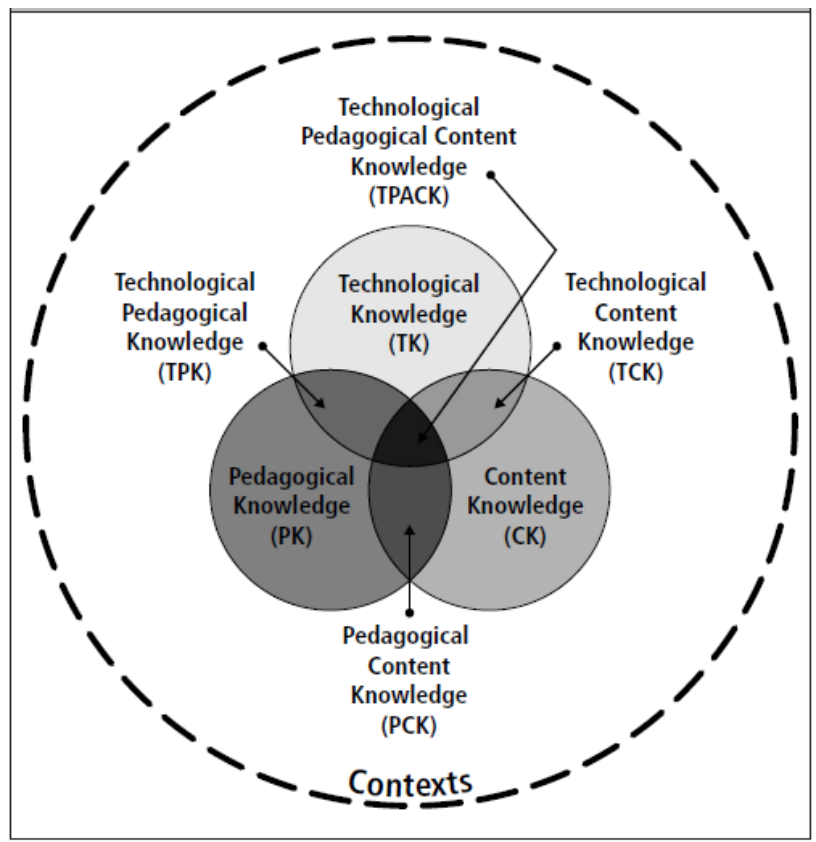

Figure 1. The TPACK framework and each knowledge domain (Koehler et al., 2013)

TPACK is a framework developed by Mishra \& Koehler (2006) by adapting Pedagogical Content Knowledge (PCK) of L. Shulman $(1986,1987)$ theories with added technology domain within it. TPACK framework is established as the theoretical framework that not only considering the relationship between technology and teaching but also capable in changing the concept and practice within teacher education (Mishra \& Koehler, 2006). Koehler et al., (2014) emphasized that it is necessary for teachers in having an understanding of all components within TPACK as the reason of each element of technology, pedagogy, and content knowledge should be integrated and to be managed all together.

\subsection{TPACK and pre-service teachers' lesson plan}

Pre-service teachers' acquisition of technology, pedagogy, and content knowledge are much different compared to in-service teachers. However, inservice teachers are facing difficulties in planning of the use technology for classroom practices (Christ et al., 2019) and it might be resulted from their teacher preparation program that less considering the support related to technology integration. However, there are several frameworks that propose the theory and models that are able in improving the teachers capacities and technology integration (Lai \& Lin, 2018, p.445) and TPACK is one of framework that bring up a solution in how to integrate technology with pedagogy and content knowledge (Koehler et al., 2014). Besides that, TPACK framework also mainly functioned in to describe the technology integration effort for lesson design practices (N. Janssen \& Lazonder, 2016).

Lesson plan have a crucial role for classroom practices. For teacher preparation program especially novice teachers, lesson plan is crucial aspects in preparing successful teaching-learning processes (Clark, 1988). Lesson plan also provided learning opportunity in which teachers should also consider the 
integrated knowledge of technology, pedagogy, and content domains (Koehler \& Mishra, 2005). In designing lesson plan, pre-service teachers are facing challenges as the reason of not enough support related to lesson design integrated with technology (N. Janssen \& Lazonder, 2016). Several studies show significant positive impact in recruiting lesson plan project to improve TPACK knowledge; (Angeli \& Valanides, 2009); based on the support of teacher program (Noortje Janssen \& Lazonder, 2015) and design and lesson observation (Bell et al., 2013). Therefore, the present study built on those ideas to measure the TPACK integration of pre-service teachers within lesson plan project based on the suitability and correctness within each domain.

\section{Method}

\subsection{Respondents}

The pre-service teachers were in a master's degree in the teacher training program. The participants involved in the study were 4 out of 25 pre-service teachers from one of the universities in Central Java, Indonesia, that took part in a digital literacy course in the first semester of the year 2019. The four preservice teachers were selected randomly; the name pseudonyms are Rani (24year-old), Dian (30-year-old), Suci (25-year-old), and Dewi (24-year-old). The participants were randomly assigned based on the lesson projects that they made (2 participants with high technology integrated based and 2 participants with low technology integrated based). All of the respondents grant permission to collect and use the data for this study.

\subsection{Materials}

The digital literacy course was held around one semester and had the purpose of enabling pre-service teachers TPACK knowledge and skill. Several strategies support the TPACK enactment in the course; the theory and practice of TPACK knowledge and skill; feedback of lecture and friends related to lesson project they made; and authentic personal experiences (scaffolding) to explore and find the most suitable app and website for the lesson design project.

Therefore, to measure the TPACK enactment, this study will investigate the technology integration within their lesson designs, stories before and after take part in the course, and interview to clarify the findings.

\subsection{Procedure}

The data collection process was started by observing the classroom practices. Then, the next is collecting the lesson project that was made by the pre-service teachers. Then towards the last meeting, the story consists of past and present experiences related to technology integration, and the impact of digital literacy is collected. To triangulate the data from different sources, and ensuring the validity and reliability, interviews were implemented achieving this purpose. Triangulation is used where the intersection of three different reference points is used to calculate the precise location of an object (Yardley, 2017). The triangulation used in this study was methodological triangulation (Flick, 2018), refers to the use of multiple methods, for instance, observing participant, recording of naturally occurring data, analyzing of documents and artifacts and so on. Next, we look at the integration of other forms of data in 
interview studies, including documents, visual methods, and participant observation.

\section{Findings and Discussion}

The lesson plans of all the participants were analyzed by focus on the domain TPACK (Mishra \& Koehler, 2006) and justified the learning activities quality of lesson plan whether the support materials included the integrated domain of technology, pedagogy, and content knowledge. Then, investigating a critical factor in which gave challenges for pre-service teachers in integrating technology seen from the perspective of Christ et al. (2019). The data analysis used thematic analysis, which provides detailed data that can be confirmed according to the needs so that it is a flexible approach. It has a highly flexible approach that can be modified for the needs of many studies, providing a rich and detailed, yet complex account of data (Braun \& Clarke, 2006).

\subsection{Core Knowledge Basis}

TPACK consists of the knowledge domain of technology, content, and pedagogy. This study will explore the lesson step and seven knowledge-based represented on the lesson design.

Table 2. Describe TPACK

\begin{tabular}{|c|c|}
\hline $\begin{array}{l}\text { Knowledge } \\
\text { Components }\end{array}$ & Description \\
\hline $\begin{array}{l}\text { Content } \\
\text { knowledge } \\
\text { (CK) }\end{array}$ & $\begin{array}{l}\text { In the lesson design, overall of the pre-service teachers have been } \\
\text { representing the suitable subject matter and knowledge material. } \\
\text { Most of them used authentic materials which the students were } \\
\text { familiar enough. }\end{array}$ \\
\hline $\begin{array}{l}\text { Pedagogical } \\
\text { knowledge } \\
\text { (PK) }\end{array}$ & $\begin{array}{l}\text { Suci, Dian, and Dewi preferred to see more observable learning } \\
\text { outcomes, such as comprehending the main idea and identifying } \\
\text { text structure, as the indicators of the lesson plan. While Rani } \\
\text { preferred to determine communication purposes (performing self- } \\
\text { introduction) as the indicators of her lesson plan. }\end{array}$ \\
\hline $\begin{array}{l}\text { Technology } \\
\text { knowledge } \\
\text { (TK) }\end{array}$ & $\begin{array}{l}\text { Dian and Suci were making a lesson plan using low technology. } \\
\text { Dewi and Rani were using high tech websites or applications for } \\
\text { their lesson plans. } \\
\text { In the undergraduate program, all of the pre-service teachers have } \\
\text { been taking part in the technology course. Therefore, there was no } \\
\text { major problem in integrating technology for their lesson plan. }\end{array}$ \\
\hline $\begin{array}{l}\text { Pedagogical } \\
\text { content } \\
\text { knowledge } \\
\text { (PCK) }\end{array}$ & $\begin{array}{l}\text { Most of the participants were representing the content area with } \\
\text { several learning styles that were determined to achieve the learning } \\
\text { outcomes. Such as the use of visual along with written form by } \\
\text { using You tube video, to make the students easily understand the } \\
\text { new vocabulary through visualizing the concept or the thing. Dian } \\
\text { did not provide the appropriate or balance materials which cover all } \\
\text { students learning style, because she just provided written } \\
\text { materials, so that they are appropriate for them who are visual } \\
\text { learners. Furthermore, beforing entering to the main activity, she } \\
\text { did not activate students pior knowledge by not giving them chance } \\
\text { to share their opinions regarding the topic. The material used was } \\
\text { less authentic because it was out of the students context. }\end{array}$ \\
\hline $\begin{array}{l}\text { Technological } \\
\text { pedagogical }\end{array}$ & $\begin{array}{l}\text { The technology was used by all participants to convey the } \\
\text { information and they used tests to assess students' performance by }\end{array}$ \\
\hline
\end{tabular}




\begin{tabular}{|c|c|}
\hline $\begin{array}{l}\text { knowledge } \\
\text { (TPK) }\end{array}$ & $\begin{array}{l}\text { using technology. Participants used technology to make the } \\
\text { students do discovery learning by finding the most suitable } \\
\text { materials as the references of the students in making a text or fulfill } \\
\text { their task. }\end{array}$ \\
\hline $\begin{array}{l}\text { Technological } \\
\text { content } \\
\text { knowledge } \\
\text { (TCK) }\end{array}$ & $\begin{array}{l}\text { Some participants mostly used technology without considering the } \\
\text { effectiveness of classroom practice. It was shown from Rani's } \\
\text { lesson that using two applications that time-consuming, and it was } \\
\text { not effective if they had a bad connection. }\end{array}$ \\
\hline $\begin{array}{l}\text { Technological, } \\
\text { pedagogical, } \\
\text { and content } \\
\text { knowledge } \\
\text { (TPACK) }\end{array}$ & $\begin{array}{l}\text { The lesson plans that they made mostly asked the students to } \\
\text { discuss and present the materials. The learning process has been } \\
\text { a concern by all the participants, but the advantage of technology in } \\
\text { their lesson design is a bit not clear with the indicators. The } \\
\text { pedagogies were less emerged, because most of them were giving } \\
\text { knowledge, testing, and providing feedback, rather than activating } \\
\text { students' curiosity. }\end{array}$ \\
\hline
\end{tabular}

\section{a. Content Knowledge}

Content knowledge (CK) is described as the areas or subject matter related that taught by teachers (Koehler \& Mishra, 2005). Lesson design represented by four pre-service teachers has been suitable for the subject matter of English subject.

\section{b Pedagogical Knowledge}

Pedagogical Knowledge or PK is related to 'the skills, beliefs, and knowledge related to the teaching of a particular subject area' (Pamuk, 2012, p.7). The lesson design that participants made is using the Product Oriented Approach (POA). This approach has the purpose of enabling the students to produce any product with several steps of motivating and enabling the students to engage in learning processes. Besides that, the participants were also connecting the approaches of language learning, such as cognitivism and behaviorism approach in considering the way to teach language learning.

\section{c Technological Knowledge}

Technological Knowledge or TK is describing the use of modern (internet, digital video, and so on) a common technology (book, blackboard, PowerPoint, and so on) (Koehler \& Mishra, 2005). All the participants have applied several technologies in their lesson plan, both high and low technologies.

Suci's lesson design was focused on using low technology. Suci chose 'Youtube' as the technology aspect for her lesson design to teach speaking skills. Based on her story, she loves to use Youtube and an online dictionary to learn English. At first, Suci was afraid to use technology and argue that it is impossible to apply it in her hometown. However, after enrolling in a digital literacy class, she realized that there are a lot of free downloadable materials that can be used for classroom practices.

Dian used common technologies like PowerPoint, The Jakarta Post website, and Kamus Bahasa Inggris and Indonesia (English-Indonesian dictionary) to teach the reading skill. She determined to use low technology for her lesson design. She believed that learning through technology, both common and modern technology will facilitate the students in acquiring a language. 
However, the needs of buildup students' motivation should be emphasized more when integrating technology in classroom practices.

Rani made a high technology lesson plan integrated with the use of Skype and Youtube to teach students' speaking skills. In her undergraduate program, most of her teachers are using presentations and handouts. She argued that it is possible to use the same technology for her lesson design, but she thought that in acquiring language skill, it is better for the students to be helped by the use of modern technology to make them more engaged in the teaching-learning process.

Dewi used Google Arts \& Culture and Write About to teach writing skills. The high technology was used for her lesson plan. She argued that implementing the use of technology in the classroom will make the students comprehend knowledge deeply. She argued that technology is a powerful tool to help the teaching-learning process.

\section{d. Pedagogical Content Knowledge}

Pedagogical content knowledge (PCK) is describing the content area with several learning styles that were determined to achieve the learning outcomes (Mishra \& Koehler, 2006). The participants did not have any issues in determining the content of the subject matter. To help activate the prior knowledge, the students are given several times to discuss and share their opinion related to the issue. A participant did not provide learning materials that cover the different students learning style, she provided written materials only.

\section{e. Technological Pedagogical Knowledge}

Technological pedagogical knowledge (TPK) is knowledge of 'existence, components, and capabilities of various technology' used in the classroom, and knowing that teaching might change as resulting from the use of technology (Mishra \& Koehler, 2006). Understanding the tools, fitness, strategies for the tools, and apply the strategy for the use of technology are the aspect that should be considered within this domain.

All the participants have already known and they were familiar with the tools that they used for the lesson plan. They already explored how to apply, create through the tools, and benefit of the tools in improving students' language skills.

However, there was a participant that a little bit was not fit in using technology for her lesson design. It was shown from the lesson plan, which demanded the students to make a video and using video conference at the same meeting. The plan that was made is clearly impossible to be achieved in a meeting. Rani, had difficulties in determining the fitness of the technology, and the strategy of producing video at the end of meeting is difficult to be achieved.

\section{f. Technological Content Knowledge}

Technological content knowledge (TCK) is described as the relation of both domains of content knowledge and technology (Mishra \& Koehler, 2006). All participants were already considering the subject matter and the matter of manner of the application. For example, Dewi wanted to improve students 
reading skill by using Google Arts \& Culture. Besides it is colorful and fun, it motivated them to read the passage as many modes like visual expected to make them motivated in learning. With 360 degrees landscape, students could feel as they were taking a tour also at the same time engage for reading skill through the passage that provided there.

\section{g. Technological, Pedagogical, and Content Knowledge}

The data demonstrate the participants still have a lack of understanding of technology integration within TPACK in some domains. Some participants emphasized on the use of technology instead of concern on the educational ideas. Also, the lesson plan that they made mostly asked the students to discuss and present the materials. The teacher position in the lesson plan is as the one provide the materials; this might be as the reason for lack of pedagogical experiences. The teaching methodologies they used seem to be less appropriate because they did not activate students curiosity because they should explain many materials.

\subsection{Challenges in Integrating Technology}

In selecting and planning the lesson design, all of the participants were facing several challenges. The most frequent challenge faced by students is that technology did not plan effectively, especially several modern technologies such as Skype that need high internet connectivity. However, although so, the participants can overcome the challenges by giving another option of video recording of a video call to avoid some technical problems. Also, the other challenge is the participants mostly face a situation that difficult to find appropriate text based on the students' language level. The material provided in the websites and/ or applications seem to be less authentic if compared in students contexts.

Table 3. Challenges in integrating technology (Christ et al., 2019)

\begin{tabular}{|c|c|c|}
\hline \multicolumn{2}{|l|}{ The Categories } & $\begin{array}{l}\text { TPACK } \\
\text { Categories }\end{array}$ \\
\hline \multicolumn{3}{|c|}{ Technology selection and planning } \\
\hline $\begin{array}{l}\text { Inappropriate text } \\
\text { level }\end{array}$ & $\begin{array}{l}\text { There was a difficulty in choosing } \\
\text { the appropriate text toward the } \\
\text { language level of students. }\end{array}$ & PCK \\
\hline $\begin{array}{l}\text { Technology } \\
\text { selection did not } \\
\text { have affordances } \\
\text { that supported the } \\
\text { objective }\end{array}$ & $\begin{array}{l}\text { All of the participants argue that } \\
\text { most technology selections have } \\
\text { affordances to support the } \\
\text { objective of learning. }\end{array}$ & TCK \\
\hline $\begin{array}{l}\text { Did not plan } \\
\text { effectively for the } \\
\text { use of the } \\
\text { technology selected }\end{array}$ & $\begin{array}{l}\text { Using several technologies in the } \\
\text { lesson plans decreased the time } \\
\text { allocation as the reason for a } \\
\text { need to teach the learners to } \\
\text { learn how to use technology. }\end{array}$ & TPK \\
\hline
\end{tabular}




\section{Conclusion}

These case studies explore the pre-service teachers' technology integration analyzed from their lesson plan. The teacher education program has been considering several support and strategies to make the pre-service teachers enable their TPACK, and based on the evidence, the lesson designs that were created by the pre-service teachers has been representing several domains of TPACK. Developing TPACK needs a lot of practice, experience, and knowledge, by asking the pre-service teachers to do the project of lesson design; it is one way to enable their TPACK.

During the program, the domains that were not reflected significant development are the domain of TPK and PCK. In the domain TPK teachers were a bit not fit in using technology for her lesson design as the reason for lack experiences practice to manage which technology is too demanding classroom practices. While in the domain PCK, some participants are not not provide the appropriate or balance materials which cover all students learning style.However, overall the support domain has been represented thoroughly on the lesson design made by pre-service teachers. Not avoidable in working the project, pre-service teachers facing several challenges such as difficulty in choosing the appropriate text toward the language level of students, it takes time. Then using several technologies in the lesson plan decreased the time allocation of learning processes as the reason teachers need to teach the students to learn the technology first. The participants emphasized that those challenges are difficult to overcome; otherwise, the teachers were experienced enough to manage the classroom. The pre-service teachers expected that after producing the project of the lesson plan, they hope that they can practice real classroom practices. They think that by providing actual practices for the magister degree level, they will find how to experiences TPACK knowledge in practical practices and find the classroom challenges and can overcome them together with friends and lectures.

This study has at least one implication, especially for teacher preparation programs that expected to provide more support and strategies to have a significant influence in developing technology integration for future teachers. Further research that considering the lesson design practice to explore the enabling of TPACK through any other strategies or specific strategies is needed to be conducted. Effective support will influence the successful implementation of technology integrated for educational practices.

\section{References}

Angeli, C., \& Valanides, N. (2009). Epistemological and methodological issues for the conceptualization, development, and assessment of ICT-TPCK: Advances in technological pedagogical content knowledge (TPCK). Computers \& Education, 52(1), 154-168. https://doi.org/10.1016/j.compedu.2008.07.006

Bell, R. L., Maeng, J. L., \& Binns, I. C. (2013). Learning in context: Technology integration in a teacher preparation program informed by situated learning theory. Journal of Research in Science Teaching, 50(3), 348-379. https://doi.org/10.1002/tea.21075 
Braun, V., \& Clarke, V. (2006). Using thematic analysis in psychology. Qualitative Research in Psychology, 3(2), 77-101. https://doi.org/10.1191/1478088706qp063oa

Caena, F., \& Redecker, C. (2019). Aligning teacher competence frameworks to 21st century challenges: The case for the European Digital Competence Framework for Educators ( DIGCOMPEDU). European Journal of Education, ejed.12345. https://doi.org/10.1111/ejed.12345

Christ, T., Arya, P., \& Liu, Y. (2019). Technology Integration in Literacy Lessons: Challenges and Successes. Literacy Research and Instruction, 58(1), 49-66. https://doi.org/10.1080/19388071.2018.1554732

Clark, C. M. (n.d.). Teacher Preparation: Contributions of Research on Teacher Thinking. 8.

Fereday, J., \& Muir-Cochrane, E. (2006). Demonstrating rigor using thematic analysis: A hybrid approach of inductive and deductive coding and theme development. 5(1), 80-92.

Flick, U. (Ed.). (2018). The Sage handbook of qualitative data collection. Sage Reference.

Gill, L., \& Dalgarno, B. (2017). A qualitative analysis of pre-service primary school teachers' TPACK development over the four years of their teacher preparation programme. Technology, Pedagogy and Education, 26(4), 439-456. https://doi.org/10.1080/1475939X.2017.1287124

Janssen, N., \& Lazonder, A. W. (2016). Supporting pre-service teachers in designing technology-infused lesson plans: Support for technology-infused lessons. Journal of Computer Assisted Learning, 32(5), 456-467. https://doi.org/10.1111/jcal.12146

Janssen, Noortje, Knoef, M., \& Lazonder, A. W. (2019). Technological and pedagogical support for pre-service teachers' lesson planning. Technology, Pedagogy and Education, 28(1), 115-128. https://doi.org/10.1080/1475939X.2019.1569554

Janssen, Noortje, \& Lazonder, A. W. (2015). Implementing Innovative Technologies Through Lesson Plans: What Kind of Support Do Teachers Prefer? Journal of Science Education and Technology, 24(6), 910-920. https://doi.org/10.1007/s10956-015-9573-5

Koehler, M. J., \& Mishra, P. (2005). What Happens When Teachers Design Educational Technology? The Development of Technological Pedagogical Content Knowledge. Journal of Educational Computing Research, 32(2), 131-152. https://doi.org/10.2190/0EW7-01WB-BKHL-QDYV

Koehler, M. J., Mishra, P., \& Cain, W. (2013). What is Technological Pedagogical Content Knowledge (TPACK)? Journal of Education, 193(3), 13-19. https://doi.org/10.1177/002205741319300303

Koehler, M. J., Mishra, P., Kereluik, K., Shin, T. S., \& Graham, C. R. (2014). The Technological Pedagogical Content Knowledge Framework. In J. M. Spector, M. D. Merrill, J. Elen, \& M. J. Bishop (Eds.), Handbook of 
Research on Educational Communications and Technology (pp. 101111). Springer New York. https://doi.org/10.1007/978-1-4614-3185-5_9

Lai, T., \& Lin, H.-F. (2018). An investigation of the relationship of beliefs, values and technological pedagogical content knowledge among teachers. Technology, Pedagogy and Education, 27(4), 445-458. https://doi.org/10.1080/1475939X.2018.1496137

Mishra, P., \& Koehler, M. J. (2006). Technological Pedagogical Content Knowledge: A Framework for Teacher Knowledge. Teachers College Record, 108(6), 1017-1054. https://doi.org/10.1111/j.14679620.2006.00684.x

Pamuk, S. (2012). Understanding preservice teachers' technology use through TPACK framework: Preservice teachers' technology use. Journal of Computer Assisted Learning, 28(5), 425-439. https://doi.org/10.1111/j.1365-2729.2011.00447.x

Redmond, P., \& Peled, Y. (2019). Exploring TPACK among pre-service teachers in Australia and Israel. British Journal of Educational Technology, 50(4), 2040-2054. https://doi.org/10.1111/bjet.12707

Shulman, L. (1987). Knowledge and Teaching: Foundations of the New Reform. Harvard Educational Review, 57(1), 1-23. https://doi.org/10.17763/haer.57.1.j463w79r56455411

Shulman, L. S. (n.d.). Those Who Understand: Knowledge Growth in Teaching. 11.

Tsai, P.-S., \& Tsai, C.-C. (2019). Preservice teachers' conceptions of teaching using mobile devices and the quality of technology integration in lesson plans: Conceptions of teaching using mobile devices. British Journal of Educational Technology, 50(2), 614-625. https://doi.org/10.1111/bjet.12613

Valtonen, T., Sointu, E., Kukkonen, J., Mäkitalo, K., Hoang, N., Häkkinen, P., Järvelä, S., Näykki, P., Virtanen, A., Pöntinen, S., Kostiainen, E., \& Tondeur, J. (2019). Examining pre-service teachers' Technological Pedagogical Content Knowledge as evolving knowledge domains: A longitudinal approach. Journal of Computer Assisted Learning, 35(4), 491502. https://doi.org/10.1111/jcal.12353

Yardley, L. (2017). Demonstrating the validity of qualitative research. The Journal of Positive Psychology, 12(3), 295-296. https://doi.org/10.1080/17439760.2016.1262624 